\title{
Peningkatan KeterampilanMemberikan Tanggapan Melalui Strategi The Power Of Two Pada Siswa SMP Negeri 2 Selakau
}

\author{
Mauluda Nurhidayah ${ }^{1}$, Fitri $^{2}$, Sri Mulyani ${ }^{3}$ \\ STKIP Singkawang, Singkawang, Indonesia \\ mauludanurhidayah2@gmail.com ${ }^{1}$, fitri_djayadi@gmail.com ${ }^{2}$, srimulyani.stkip@gmail.com ${ }^{3}$
}

\author{
Kata Kunci : \\ Tanggapan, The Power Of \\ Two
}

\begin{abstract}
ABSTRAK
Penelitian ini bertujuan untuk mendeskripsikan Perencanaan, pelaksanaan, dan hasil memberikan tanggapan melalui strategi pembelajaran the power of two pada siswa kelas VIII C SMP Negeri 2 Selakau. Penelitian ini merupakan penelitian kualitatif, dengan menggunakan metode kualitatif deskriftif. Data penelitian berupa proses pembelajaran memberikan tanggapan dan hasil belajar siswa dengan menerapkan strategi pembelajaran the power of two. Teknik pengumpulan data menggunakan pengukuran dan observasi. Prosedur penelitian ini terdiri dari dua siklus dengan langkah-langkah: (1) perencanaan, (2) tindakan, (3) Observasi, (4) refleksi. Kesimpulan dalam penelitian ini adalah penerapan strategi pembelajaran the power of two dalam penelitian tindakan kelas dapat meningkatkan kualitas proses pembelajaran berbicara memberikan tanggapan. Hal ini dibuktikan dengan peningkatan keterampilan guru dalam mengelola pembelajaran, dan kegiatan dalam partisipasi siswa dalam mengikuti proses pembelajaran. Kinerja guru dalam mengelola pembelajaran terus meningkat dari $75 \%$ pada siklus 1 menjadi 85,72\% pada siklus 2. Nilai kegiatan aktivitas siswa di kelas mengikuti proses pembelajaran pada siklus 1 mencapai $74,33 \%$ meningkat menjadi 83,33\% pada siklus 2. Peningkatan belajar siswa dapat diketahui setelah membandingkan hasil, sebelumnya pada keterampilan berbicara hanya mencapai $40 \%$, setelah mendapat tindakan siklus I persentase ketuntasan menjadi 60\%. Terjadi peningkatan pada siklus II yaitu $85 \%$ mencapai pada peningkatan yang diharapkan.
\end{abstract}




\section{PENDAHULUAN}

Perkembangan zaman di dunia pendidikan terus berubah dengan signifikan sehingga banyak merubah pola pikir pendidik, dari pola pikir yang awam dan kaku menjadi lebih modern. Hal tersebut sangat berpengaruh dalam kemajuan pendidikan di Indonesia.Tujuan pendidikan adalah menciptakan seseorang yang berkualitas dan berkarakter sehingga memiliki pandangan yang luas kedepan untuk mencapai suatu cita- cita yang diharapkan dan mampu beradaptasi secara cepat dan tepat di dalam berbagai lingkungan, karena pendidikan itu sendiri memotivasi diri kita untuk lebih baik dalam segala aspek kehidupan.

Pembelajaran bahasa Indonesia terdiri atas dua jenis keterampilan yaitu keterampilan berbahasa dan keterampilan bersastra. Pembelajaran keterampilan berbahasa Indonesia mencakup keterampilan menyimak, berbicara, membaca, dan menulis. Dilihat dari sifatnya, keterampilan menyimak dan membaca bersifat reseptif yaitu menerima atau memahami pesan yang disampaikan oleh pembicara atau penulis. Sedangkan berbicara dan menulis bersifat produktif, artinya menghasilkan pembicaraan atau tulisan. Setiap keterampilan itu erat sekali berhubungan dengan proses-proses berpikir yang mendasari bahasa. Bahasa seseorang mencerminkan pikiran.Pembelajaran berbicara merupakan salah satu aspek keterampilan berbahasa. Berbicara adalah keterampilan yang berkembang pada kehidupan anak, yang didahului oleh keterampilan menyimak. Pada masa tersebutlah keterampilan berbicara atau terujar di pelajarai (Tarigan, 2008:3).

Berdasarkan praobservasi yang dilakukan penulis di sekolah SMP Negeri 2 Selakau menunjukkan bahwa keterampilan siswa dalam berbicara memberikan tanggapan dengan bahasa yang baik dan benar serta santun kurang dikuasai oleh siswa. Padahal berbicara merupakan faktor yang sangat penting bagi siswa untuk berkomunikasi. Permasalahan utama yang dihadapi siswa dalam hal ini adalah kurangnya motivasi siswa terhadap kegiatan memberikan tanggapan pada kutipan novel remaja sehingga menyebabkan hasil belajar siswa dalam hal berbicara rendah. Tanggapan adalah bayangan yang tinggal dalam ingatan setelah kita melakukan pengamatan (Suryabrata, 2005:38).

Selain hal tersebut penggunaan model pembelajaran yang dipilih oleh guru juga mempengaruhi keberhasilan proses pembelajaran. Dari hasil praobservasi yang dilakukan penulis membuktikan di SMP Negeri 2 Selakau ,bahwa hasil belajar siswa dalam berbicara pada kelas VIII A mencapai ketuntasan 70,83\%, kelas VIII B 62,5\%, dan kelas VIII C 40\% dari nilai kriteria ketuntasan minimum (KKM) yang ditentukan sekolah yaitu 75,00. Jika dilihat dari hasil belajar siswa pada tiap kelas maka kelas VIII C merupakan kelas yang terendah dari pencapaian hasil belajar. Oleh karena itu, kegagalan yang berwujud rendahnya hasil belajar berbicara dipengaruhi oleh faktor tertentu, seperti masih kurangnya penerapan strategi pembelajaran dalam proses pembelajaran, lingkup belajar dan karakteristik siswa tersebut.

Alternatif yang dapat digunakan untuk meningkatkan hasil belajar siswa yaitu dengan menerapkan strategi pembelajaran aktif the power of two pada pembelajaran berbicara. Silberman (2014:173) menyatakan Strategi pembelajaran aktif the power of two artinya menggabungkan kekuatan dua orang. Pembelajaran aktif the power of two adalah kegiatan yang digunakan untuk meningkatkan pembelajaran dan menegaskan manfaat dari sinergi yakni, bahwa dua kepala adalah lebih baik dari pada satu.

Penelitian relevan dengan materi yang sama tetapi menggunakan strategi yang berbeda dilakukan oleh Mariani Wulan Putri (2015) dengan judul "peningkatan kemampuan berbicara memberikan tanggapan dengan menggunakan metode talking stick pada siswa kelas VIII SMP Negeri 4 Denpasar tahun ajaran 2015/2016". Hasil penelitian menunjukkan bahwa kemampuan siswa dalam memberikan tanggapan dengan metode talking stick telah mencapai hasil yang optimal. Hasil tes memberikan tanggapan pada siklus I diperoleh nilai rata-rata 6,61. Setelah dilakukan tindakan siklus II diperoleh nilai rata-rata 7,75. Nilai rata-rata pada siklus II menunjukkan peningkatan sebesar 1,14 dibandingkan dengan nilai rata-rata pada siklus I. Berdasarkan hasil tes pada siklus III dapat diketahui bahwa nilai rata-rata sebesar 8,56. Hasil yang diperoleh pada sklus III sudah memenuhi ketuntasan yang diharapkan sebesar 8,00 dengan kategori baik. 
Berdasarkan masalah tersebut, peneliti ingin melakukan penelitian dengan judul "Peningkatan Keterampilan Memberikan Tanggapan Melalui Strategi Pembelajaran The Power Of Two pada Siswa kelas VIII C SMP Negeri 2 Selakau Tahun Ajaran 2017/2018. Penulis memilih strategi the power of two untuk meningkatkan keterampilan berbicara khususnya dalam memberikan tanggapan karena dinilai paling cocok dibanding model atau strategi pembelajaran yang lain. the power of two dapat memberi siswa lebih banyak waktu berfikir, untuk merespon dan saling membantu. Siswa bekerja secara berpasangan sehingga siswa termotivasi untuk belajar dan suasana pembelajaran lebih menyenangkan.

\section{METODE}

Jenis penelitian yang digunakan adalah deskriptif. Metode penelitian deskriptif merupakan data yang dikumpulkan berupa kata-kata, gambar dan bukan angka-angka (Moleong, 2014:11). Bentuk penelitian yang digunakan dalam penelitian ini adalah bentuk penelitian kualitatif. Menurut Sukmadinata (2010:60) bahwa penelitian kualitatif adalah suatu penelitian yang bertujuan untuk mendeskripsikan dan menganalisis fenomena, peristiwa, aktivitas sosial, sikap, kepercayaan, persepsi, pemikiran orang secara individual maupun kelompok. Dengan demikian, dalam rencana penelitian ini akan dijelaskan mengenai peningkatan keterampilan berbicara memberikan tanggapan melalui strategi the power of two.

Setting penelitian adalah lokasi tempat penelitian berlangsung, meliputi situasi fisik, keadaan siswa, suasana, serta hal-hal lain yang banyak berpengaruh terhadap tindakan yang dilakukan oleh guru ketika penelitian tindakan berlangsung (Arikunto, 2016:76).

Rancangan penelitian ini menggunakan penelitian tindakan kelas. Penelitian tindakan kelas merupakan suatu pencermatan terhadap kegiatan belajar berupa sebuah tindakan yang sengaja dimunculkan dan terjadi dalam sebuah kelas secara bersamaan (Suwandi, 2011:12). Penelitian tindakan kelas adalah kajian tentang situasi sosial dengan maksud untuk meningatkan kualitas tindakan di dalamnya, John Elliot (dalam burhan 2013:20). Berdasarkan pernyataan tersebut, berarti bahwa sebagai perencana dan pelaksana proses pembelajaran, guru dituntut selalu mengupayakan untuk memahami kondisi permasalahan di dalam kelas.

Data dalam rencana penelitian ini terdiri atas dua data yang sekaligus menjadi fokus penelitian, yakni proses pembelajaran memberikan tanggapan dan hasil belajar siswa melalui strategi pembelajaran the power of two. Data diperoleh secara langsung dari proses pembelajaran memberikan tanggapan dengan menggunakan strategi pembelajaran The Power of Two pada siswa kelas VIII C SMP Negeri 2 Selakau. Sumber data dalam penelitian ini adalah guru bahasa Indonesia yang bernama Karmila dan siswa kelas VIII C yang berjmlah 20 siswa terdiri dari 9 siswa laki-laki dan 11 siswa perempuan. Sejalan dengan data yang akan dikumpulkan serta sumber data yang ada, selanjutnya akan dikemukakan mengenai teknik pengumpulan data. Adapun teknik pengumpul data dalam penelitian ini adalah teknik observasi langsung, dan teknik pengukuran. Alat pengumpul data yang digunakan dalam penelitian ini adalah lembar observasi, panduan wawancara, tes dan dokumentasi

Teknik analisis data adalah proses mencari dan menyusun secara sistematis data yang diperoleh dari hasil wawancara, catatan lapangan, dan dokumentasi, dengan cara mengorganisasikan data ke dalam kategori, menjabarkan ke dalam unit-unit, melakukan sintesa, menyusun ke dalam pola, memilih nama yang penting dan yang akan dipelajari, dan membuat kesimpulan sehingga mudah dipahami oleh diri sendiri maupun orang lain (Sugiyono, 2015: 335). Teknik analisis data yang digunakan dalam rencana penelitian ini yaitu teknik deskriptif komparatif dan teknik analisis kritis.

\section{HASIL DAN PEMBAHASAN}

Pembelajaran memberikan tanggapan meningkat dilakukan dalam dua siklus, setiap siklus terdiri dari empat tahapan, yaitu perencanaan, pelaksanaan, pengamatan dan refleksi. Meningkatnya hasil pembelajaran keterampilan berbicara memberikan tanggapan menyimak dibuktikan bahwa dalam pelaksanaan penelitian ini diperoleh dari hasil tindakan siklus I, dan siklus II. Setiap tahapan penelitian 


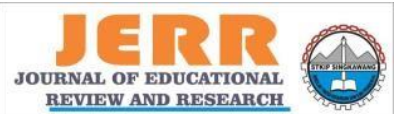

\section{Journal of Educational Review and Research}

Vol. 3 No. 1, July 2020. Page: 1 - 5

e-ISSN: 2597-9760, p-ISSN: 2597-9752

mulai dari pra tindakan, siklus I, dan Sikus II dalam meningkatkan keterampilan memberikan tanggapan dengan menggunakan strategi pembelajaran the power of two berjalan dengan baik melalui berbagai perbaikan pada setiap siklus sehingga mencapai tujuan pembelajaran yaitu meningkatkan keterampilan memberikan tanggapan.

Melalui tahap perencanaan kegiatan pembelajaran, peneliti dan kolaborator berdiskusi untuk menyusun kegiatan pembelajaran. Perencanaan pembelajaran yang telah disusun dari siklus 1 dan siklus 2 mengalami peningkatan. Perencanaan yang dibuat telah sesuai dengan kriteria penilaian. Dalam perencanaan pembelajaran siklus I mencapai 76,25\% dan siklus 2 mencapai 85\%. Dengan demikian dapat dikatakan bahwa perencanaan pembelajaran mengalami peningkatan yaitu 8,75\%. Berdasarkan hasil peningkatan tersebut maka hasil pembelajaran juga akan meningkat menjadi lebih baik.

Selanjutnya pada pelaksanaan pembelajaran memberikan tanggapan menggunakan strategi the power of two setiap siklusnya mengalami peningkatan. Dalam pelaksanaan pembelajaran memberikan tanggapan pada siklus 1 mencapai $75 \%$ dan siklus 2 mencapai $85,72 \%$, dengan demikian dapat dikatakan bahwa pelaksanaan pembelajaran mengalami peningkatan yaitu 10,72 \%. Pelaksanaan pembelajaran dilakukan sangat baik oleh guru bahasa indonesia.

Dalam kegiatan penelitian, peneliti juga mengamati aktivitas siswa selama proses pembelajaran berlangsung. Peneliti menggunakan lembar observasi aktivitas siswa selama proses pembelajaran berlangsung. Aktivitas siswa selama proses pembelajaran memberikan tanggapan pada siklus 1 mencapai $74,33 \%$ dan siklus 2 mencapai 84,33\%, artinya mengalami peningkatan sebesar 10\%. Berdasarkan hasil peningkatan aktivitas siswa tersebut maka hasil pembelajaran juga akan meningkat menjadi lebih baik.

Untuk mengetahui peningkatan hasil belajar memberikan tanggapan perlu adanya tes yang diberikan kepada siswa yang berhubungan dengan materi yang telah diberikan guru. Dari hasil tes memberikan tanggapan pada siswa kelas VIII C SMP Negeri 2 Selakau menunjukkan adanya peningkatan hasil belajar siswa dari mulai pra tindakan sebelum menggunakan strategi pembelajaran the power two, siklus I dan siklus II setelah menggunakan strategi pembelajaran the power of two.

Meningkatnya hasil nilai keterampilan memberikan tanggapan pada siswa kelas VIII C SMP Negeri 2 Selakau setelah menerapkan strategi pembelajaran the power of two dalam pembelajaran. Hal ini ditunjukan dengan adanya peningkatan nilai pada setiap siklus. Aspek-aspek yang dinilai dalam menyimak pembacaan cerpen adalah mengungkapkan hal-hal yang menarik tentang tema, alur, amanat serta menanggapi komentar teman tentang novel. Peningkatan keterampilan memberikan tanggapan akan dijelaskan secara keseluruhan mulai dari pra tindakan, siklus I, dan siklus II dapat dilihat pada Tabel 1 sebagai berikut.

Tabel 1. Hasil Keseluruhan Tindakan

\begin{tabular}{llcccc}
\hline No & \multicolumn{1}{c}{ Siklus } & $\begin{array}{c}\text { Jumlah } \\
\text { Siswa }\end{array}$ & \multicolumn{2}{c}{ Nilai } & $\begin{array}{c}\text { Nilai Rata- } \\
\text { rata }\end{array}$ \\
\hline 1 & Pra tindakan & 20 & 12 Siswa & 8 Siswa & 69,75 \\
2 & Siklus I & 20 & 8 Siswa & 12 Siswa & 73,12 \\
3 & Siklus II & 20 & 3 Siswa & 17 Siswa & 80,94 \\
\hline
\end{tabular}

Berdasarkan keseluruhan hasil mulai dari tindakan pada siklus I hingga siklus II di atas dapat disimpulkan bahwa hasil belajar siswa pada materi memberikan tanggapan pada siswa kelas VIII C SMP Negeri 2 Selakau dengan KKM 75 dari setiap tindakan penelitian terdapat peningkatan. Hal ini dapat dilihat dari peningkatan nilai rata-rata siswa pada saat menggunakan strategi pembelajaran the power of two yaitu 73,12 pada siklus I dengan dan meningkat dengan perolehan rata-rata 80,94. Persentase ketuntasan belajar siswa secara klasikal mengalami peningkatan. Sebelum diterapkannya strategi pembelajaran the power of two jumlah siswa yang tuntas atau mencapai KKM adalah 8 siswa (40\%), dan setelah menerapkan strategi pembelajaran the power of two pada siklus I siswa yang tuntas atau mencapai KKM berjumlah 12 siswa (60\%), dan pada siklus II siswa yang tuntas atau mencapai KKM berjumlah 17 siswa (85\%). Dengan adanya peningkatan ketuntasan belajar siswa tersebut, dapat disimpulkan bahwa 
strategi pembelajaran the power of two dapat meningkatkan keterampilan memberikan tanggapan pada siswa kelas VIII C SMP Negeri 2 Selakau.

\section{KESIMPULAN}

Berdasarkan analisis data dan hasil yang dilakukan dengan dua siklus dapat disimpulkan bahwa strategi The Power Of Two dapat meningkatkan keterampilan memberikan tanggapan pada kutipan novel remaja siswa kelas VIII C SMP Negeri 2 Selakau. Dalam penelitian ini mengalami peningkatan disetiap siklusnya, dibuktikan dengan beberapa hal diantaranya sebagai berikut. 1) Perencanaan pembelajaran pada siklus 1 mencapai 76,25\% termasuk dalam kategori baik, sedangkan pada siklus 2 mencapai $85 \%$ yang termasuk dalam kategori sangat baik mengalami peningkatan sebesar 8,75\%. 2) Pelaksanaan pembelajaran pada siklus I mencapai $75 \%$ dan siklus II mencapai $85,72 \%$ berarti mengalami peningkatan sebesar $10,72 \%$. 3) Aktivitas siswa selama proses pembelajaran pada siklus 1 mencapai $74,33 \%$ dan siklus 2 mencapai 84,33\%, mengalami peningkatan sebesar 10\%. 4) Hasil pembelajaran pada siklus 1 $60 \%$, sedangkan pada siklus 2 mencapai $85 \%$ terjadi peningkatan sebesar $25 \%$. Rata-rata hasil belajar yang didapatkan siswa kelas VIII C SMP Negeri 2 Selakau dalam mengikuti pembelajaran menggunakan strategi the power of two mengalami peningkatan.

\section{DAFTAR PUSTAKA}

Arikunto, Suharsimi. dkk. 2016. Penelitian Tindakan Kelas. Jakarta: PT Bumi Aksara.

Elfanany, Burhan. 2013. Penelitian Tindakan Kelas. Yogyakarta: Pinang Merah Residence Kav.14.

Moleong, Lexy J. 2014. Metodologi Penelitian Kualitatif. Bandung: Remaja Rosdakarya.

Putri, Mariani Wulan. 2015. Peningkatan Kemampuan Berbicara Memberikan Tanggapan Dengan Menggunakan Metode Talking Stick Pada Siswa Kelas VIII SMP Negeri 4 Denpasar. Skripsi Program Study Bahasa dan Sastra Indonesia: Universitas Mahasaraswati Denpasar.

Silberman, L. Melvin. 2014. Active Learning 101 Cara Belajar Siswa Aktif. Bandung: Nuansa Cendekia. Sugiyono. 2015.Metode Penelitian Pendidikan: Pendekatan Kuantitatif, Kualitatif, dan R \& D. Bandung : Alfabeta.

Sukmadinata, Nana Syaodih. 2010. Metode Penelitian Pendidikan. Bandung: Remaja Rosdakarya.

Suryabrata, Sumandi. Psikologi Pendidikan. Jakarta: PT Raja Grafindo Persada.

Suwandi, Sarwiji. 2011. Penelitian Tindakan Kelas (PTK) \& Penulisan karya Ilmiah. Surakarta: Yuma Pustaka.

Tarigan, Guntur Henry. 2008. Berbicara Sebagai Suatu Keterampilan Berbahasa. Bandung: angkasa. 